\title{
Collection Data Type
}

National Cancer Institute

\section{Source}

National Cancer Institute. Collection Data Type. NCI Thesaurus. Code C95819.

A data type comprised of a collection of values which can be enumerated using an iterator. (ISO) 